\title{
Intergraded Applied Methodology for the Treatment of Heavy Polluted Waste Waters from Olive Oil Industries
}

\author{
Antonis A. Zorpas and Vassilis J. Inglezakis \\ Laboratory of Environmental Friendly Technology, Department of Research and Development, \\ Institute of Environmental Technology and Sustainable Development, P.O. Box 34073, 5309 Paralimni, Cyprus \\ Correspondence should be addressed to Antonis A. Zorpas, antoniszorpas@envitech.org
}

Received 2 December 2010; Revised 20 January 2011; Accepted 2 March 2011

Academic Editor: Silvana I. Torri

Copyright ( 2011 A. A. Zorpas and V. J. Inglezakis. This is an open access article distributed under the Creative Commons Attribution License, which permits unrestricted use, distribution, and reproduction in any medium, provided the original work is properly cited.

The annual olive oil production in Cyprus is in the range of $2700-3100 \mathrm{t} \mathrm{y}^{-1}$, resulting in the generation of significant amount of waste. The cocomposting of the olive oil solid residue (OOSR) and the treated wastewaters (with Fenton) from the olive oil production process with the application of reed beds has been studied as an integrated method for the treatment of wastewater containing high organic and toxic pollutants under warm climate conditions. The experimental results indicated that the olive mill wastewater (OMW) is detoxified at the end of the Fenton process. Specifically, COD is reduced up to $65 \%$ (minimum $54.32 \%$ ) by the application of Fenton and another $10-28 \%$ by the application of red beds as a third stage. The final cocomposted material of OOSR with the treated olive mile wastewater (TOMW) presents optimum characteristics and is suitable for agricultural purpose.

\section{Introduction}

Olive oil production is considered one of the oldest agricultural industries in the Mediterranean countries. Approximately $1.8 \times 10^{6} \mathrm{t}$ of olive oil is produced annually worldwide, where the majority of it is produced in the Mediterranean basin [1-3]. The average amount of olive mill wastewater (OMW) produced during the milling process is 1.2 $1.8 \mathrm{~m}^{3} \mathrm{t}^{-1}$. OMW resulting from the production processes in the Mediterranean region surpasses 30 million $t$ per year $[2,3]$. The treatment of liquid wastes produced from olive oil production is still a major challenge facing this industry. The main problem is attributed to its dark colour, high organic content, and toxicity, which are due to the presence of phenolic compounds $[3,4]$. Chemical oxidation demand (COD) values of OMW may reach $150 \mathrm{~g} \mathrm{~L}^{-1}$, most of which are in a particulate form. Suspended solids up to $190 \mathrm{~g} \mathrm{~L}^{-1}$ have been recorded $[3,5]$. A common way of dealing with the OMW in many Mediterranean countries is to discharge it directly into sewer network, convey it to a central lagoon, or store it in a small pond beside the mill, where it is left to evaporate until the next season. These ponds often leak causing ground water pollution and unpleasant odours problems. Since the setting up of more stringent regulations concerning public waste disposal, there is a growing interest in the development of new technologies and procedures for the purification of this wastewater.

Today, olive tree in Cyprus is grown in compact groves or, more often, mixed with other crops such as fruit trees, carobs, and cereals. It is also found scattered on uncultivated land, steep slopes, rocky ground, or in residential areas. Some 12000 families are engaged in olive growing. The total area under olive cultivation is about $7400-8000$ ha with about 2.2-2.7 million productive trees. It is estimated that olive trees hold $44.7 \%$ of the total agricultural area under permanent crops, followed by trees producing shelled nuts with $18.5 \%$, citrus fruit with $17.3 \%$, and fruit trees of temperate crops with $12.4 \%$, [6]. This represents approximately $5.6 \%$ of the country's cropped area and contributed $2.7-2.9 \%$ of total agricultural output. The annual average olive production is about 13500-15500 t, equivalent to 2700-3100 t of olive oil. However, owing to the biennial bearing of the trees and the 
cultivation of the olives under rain-fed conditions, yields are extremely erratic, and olive production exhibits extreme fluctuations from year to year [7].

Olive mill wastewaters (OMWs) constitute a serious environmental problem in the Mediterranean Sea region due to the unique features associated with this type of agrowaste, namely, seasonal and localized production (typically between October and March), low flowrates (between 10 and $\left.100 \mathrm{~m}^{3} \mathrm{~d}^{-1}\right)$, and high and diverse organic load $[8,9]$. The quantity of olive oil mill solid waste and washing effluents (OMW) generated, and consequently the environmental impact, depends on the method of olive oil extraction used [10]. The traditional cold press method typically generates about $50 \%$ of OMW relatively to the initial weight of the olives, while the continuous centrifugation process generates $80-110 \%$ of OMW due to the continuous washing of the olive paste with warm water prior to oil separation from the paste. It is estimated that the annual OMW production in the Mediterranean Sea area exceeds $30 \times 10^{6} \mathrm{~m}^{3}$. OMW may have COD values as high as about $220 \mathrm{~g} \mathrm{~L}^{-1}$, and the organic matter mainly consists of oil, polysaccharides, sugars, polyphenols, polyalcohols, proteins, organic acids, phenols, lipids, and tannins, the former with concentrations that reach up to $10 \mathrm{~g} \mathrm{~L}^{-1}$ that are known to be biorecalcitrant $[4,9]$.

The major concerns regarding OMW treatment are: (i) organic compounds are difficult to biodegrade, (ii) seasonal production, and (iii) Olive oil manufacturing industries large areas $[9,10]$.

In Cyprus today are based 28 small olive mills which have the ability to treat all the production of olives and to produce olive oil. The annual olive oil production is in the range of $2700-3100$ t $^{-1}$ resulting in the generation of about 18225 $20925 \mathrm{ty}^{-1}$ of OMW (which is equal with the water consumption) which causes serious environmental problems, mainly due to its high organic content, $9180-10450 \mathrm{t} \mathrm{y}^{-1}$ of olive oil solid residue (OOSR), and $1620-1860 \mathrm{ty}^{-1}$ leaves. Lagooning as physical evaporation and irrigation for the OMW and typical composting for the olive oil solid residue (OOSR) are the main typical systems for the treatment of those waste until now in Cyprus.

Biological and physicochemical methods commonly used for OMW treatment include lime precipitation, incineration, land filling lagooning, anaerobic digestion, and composting are commonly used in Cyprus. Those methods (physicochemical) have the disadvantages of high cost and low efficiency. More specificly, (a) lime precipitation results in $40 \%$ reduction of the organic matter but the production of large quantities of sludge. Moreover, the effluents after precipitation as well as the chemical organic sludges that are produced, have all the toxicity of the initial vegetation water leading to serious disposal problems [11]; (b) incineration (with or without concentration) is reliable but expensive and complicated by high energy demand. Incineration is a popular technology for solid waste management that can greatly reduce the overall quantity of waste. However, at the same time, it is also associated with serious air pollution concerns [12, 13]; (c) landfilling is another means for handling solid waste, but it goes hand in hand with land occupation, groundwater contamination, and air pollution $[12,14]$; (d) lagooning is mainly a physical method for water evaporation, since a very limited biological degradation takes place; however, it has significant cost disadvantages due to land requirements and the necessity for taking special measures to protect public health [15]. Biological methods (anaerobic digestion and composting) have certain clear benefits due to their potential for the utilization of byproducts (compost for fertilizing, biogas for energy production, natural colouring substances, and proteins for cattle feed enrichment). Anaerobic digestion has the benefit of energy production but also relatively low efficiency (80\%) compared to the high capital cost of the high-technology installations and equipment $[3,16]$. Composting is the optimum method from the environmental point of view, as the organic matter is totally recovered. Furthermore, it has low fixed cost, and the final product could be marketable as a high-quality soil conditioner [17]. Composting is becoming more and more popular in waste management. In North America, composting is expected to become as popular as the collection of plastic bottles in the near future. Although it is a little overstated, an undeniable fact is that composting has more advantages when compared with land filling and incineration [12, 14, 17-22].

The objective of this paper is to study the feasibility of using an integrated method-including oxidation, composting, reed beds (as a natural filtration process), and irrigation-for the treatment of wastewater containing high organic and toxic pollutants from olive oil industries under warm climate conditions, in order to be a final solution for the treatment of OWM and OOSR.

\section{Material and Methods}

\subsection{State of the Art}

2.1.1. Oxidation Using Fenton Reactions. Fenton's method was discovered about 100 years ago, but its application as an oxidizing process for destroying toxic organics was not applied until the late 1960s [23]. Fenton reaction wastewater treatment processes are known to be very effective in the removal of many hazardous organic pollutants from water. The main advantage is the complete destruction of contaminants to harmless compounds, for example, $\mathrm{CO}_{2}$, water and inorganic salts. The Fenton reaction causes the dissociation of the oxidant and the formation of highly reactive hydroxyl radicals that attack and destroy the organic pollutants. Recently, advanced oxidation processes (AOP) have been proposed to treat relatively low-strength industrial wastewaters containing non-biodegradable substances toxic to microorganisms. Among them, the Fenton method is cost-effective, easy to apply and effective with relatively lowstrength wastewater containing organic compounds and has been applied to the decolorization of textile wastewater [2427].

The Fenton method consists of four stages. First, $\mathrm{pH}$ is adjusted to low acidity. Then, main oxidation reaction takes place at $\mathrm{pH}$ value of $3-5$. The wastewater is then 
neutralized at $\mathrm{pH}$ of 7-8 and finally precipitation occurs [28]. The oxidation mechanism in the Fenton process involves the reactive hydroxyl radical generated under acidic conditions by the catalytic decomposition of hydrogen peroxide, which reacts unselectively within $1 \times 10^{-3} \mathrm{~s}$, with organic substances $(\mathrm{RH})$, which are based on carbon chains or rings and also contain hydrogen, oxygen, nitrogen, or other elements. The reaction mechanism is as follows $[26,29,30]$ :

$$
\begin{gathered}
\mathrm{Fe}^{2+}+\mathrm{H}_{2} \mathrm{O}_{2} \longrightarrow \mathrm{Fe}^{3+}+\mathrm{OH}^{-}+{ }^{\bullet} \mathrm{OH} \\
\mathrm{RH}+\cdot \mathrm{OH} \longrightarrow \mathrm{R}^{\bullet}+\mathrm{H}_{2} \mathrm{O} \\
\mathrm{R}^{\bullet}+\mathrm{Fe}^{3+} \longrightarrow \text { product }+\mathrm{Fe}^{2+} \\
\mathrm{Fe}^{2+}+\cdot \mathrm{OH} \longrightarrow \mathrm{Fe}^{3+}+\mathrm{OH}^{-} \\
\mathrm{Fe}^{3+}+\mathrm{H}_{2} \mathrm{O}_{2} \longrightarrow \mathrm{Fe}^{2+}+\mathrm{H}^{+}+\mathrm{HO}_{2}
\end{gathered}
$$

Only a few applications of Fenton oxidation to highstrength wastewater such as effluent from a baker's yeast industry effluent or olive oil mill wastewater have been reported $[2,31]$.

The Fenton oxidative process is a method of chemical oxidation and coagulation of organic compounds. It is performed by the implementation of hydrogen peroxide $\left(\mathrm{H}_{2} \mathrm{O}_{2}\right)$ and a ferrous salt (Fenton's reagent) $[3,29,32-34]$. With the addition of Fenton's reagent, first, soluble organics are successfully oxidized, and then, with the coagulation procedure, insoluble organics are successfully removed. Fenton's reagent is suitable to process a wide variety of effluents regardless of their contaminant concentrations and nature. It is an economical system characterized by its simple application and possibility of using perfectly mixed tank reactors. The system can also be adapted to different volumes and conditions [28].

Compared to other AOPs, Fenton's reaction presents several advantages. $\mathrm{H}_{2} \mathrm{O}_{2}$ is environmentally friendly, since it slowly decomposes into oxygen and water. Besides, the abundance, lack of toxicity, and ease of removal from water makes $\mathrm{Fe}^{2+}$ the most commonly used transition metal for Fenton's reaction applications. Consequently, numerous research and fieled studies have been carried out to take advantage of the potential benefits of the use of Fenton's reaction as a remediation process for the treatment water and wastewater $[30,35,36]$.

2.1.2. Composting. Composting of organic wastes is a microbiologically mediated process with which the readily degradable organic matter in organic wastes is degraded and stabilized. During the process, part of organic $\mathrm{C}$ is released as $\mathrm{CO}_{2}$, part incorporated into microbial cells, and part humified. The organic nitrogen primarily as protein prior to composting is mineralized to inorganic $\mathrm{N}\left(\mathrm{NH}_{4}-\mathrm{N}\right.$ and $\mathrm{NO}_{3}-\mathrm{N}$ ), which is then resynthesized into other forms of organic $\mathrm{N}$ in microbial biomass and humic substances during the composting process. Degradation of organic C during composting is carried out by bacteria, fungi, and actinomycetes, depending on the stage of degradation, the characteristics of materials, and temperature $[19,37,38]$.
Composting provides a simple and a cost-effective alternative treatment method for sewage sludge by decomposing organic matter, producing a stabilized residue and disinfecting pathogens $[17,20,39,40]$. The composted product can also be used as a fertilizer or soil conditioner because of its large content of stabilized organic matter [39]. Compost contains many essential nutrients and improves soil physical and chemical properties. It is without a doubt a valuable product as compost improves soil organic matter content, nutrient availability soil aeration, and water holding capacity and reduces soil bulk density.

2.1.3. Treatment with Reed Beds. Plant species used in treatment wetlands have to be able to grow in watery, muddy, anaerobic conditions, and at the same time, they must be able to tolerate oscillations in water level, high salinity, and variations between high and low $\mathrm{pH}$ [41]. The exclusive use of helophytes for wastewater purification was suggested by several investigators [42-45]. The procedures are numerous and differ according to the type of water circulation through the plantations, species selection, and system structure (number of basins, dimensions, etc.) [45]. A general, reed beds present the following advantages: (i) operation does not require any electricity, fuel supply, or specific maintenance and can be characterized as cost-effective method, (ii) no mechanical systems are involved in the system, as reed beds do not break down, (iii) they break down organic materials, (iv) they are a natural filtration process, and (v) they remove nutrients such as nitrogen and phosphorus.

Among these helophytes, common reed (Phrugmites australis) is one of the cosmopolitan species that is commonly found on banks of lakes, rivers, and canyons, where it forms very dense beds $[46,47]$. Phragmites australis was successfully applied to wastewater purification either through reed beds $[45,48,49]$ or through natural ponds $[45,50]$. Also, it is used in treatment wetlands for wastewater as well as sludge treatment [51]. Hardej and Ozimek [52] evaluated the effect of sewage sludge on growth and morphometric parameters of $P$. australis and demonstrated the high adaptation capacity of the common reed to the sewage sludge environment, observing that the shoot density was over two times greater than that commonly found in natural systems.

Among the constructed treatment wetlands, the horizontal subsurface flow (SSF) type is a widely applied concept. Pretreated wastewater flows horizontally through the artificial filter bed, usually consisting of a matrix of sand or gravel, which is rooted by helophytes. This matrix is colonised by a layer of attached microorganisms (biofilm). Pollutant reduction is achieved by a combination of physical, chemical, and biological processes: sedimentation, filtration, precipitation, sorption, plant uptake, microbial decomposition, and microbial nitrogen transformations [53-55].

Horizontal subsurface (SSF-h) constructed wetlands have been extensively used for the treatment of domestic wastewater $[50,56,57]$ and, less frequently, of industrial sewages [58]. The use of SSF-h systems for OMW disposal can be assimilated to a direct discharge to the soil, carried out in completely controlled conditions of sewage application and without any pollution risk for agricultural soils and 
groundwater. Despite the potential benefits which could be expected from the use of SSF-h reed beds for OMW treatment, there is a lack of data about their ability in OMW pollutant removal [57].

2.2. Collection and Characterization of Raw Materials. The OMW and the OOSR have been collected from 3 several olive mills based in 3 different districts of Cyprus: the district of Famagusta (DF) which is in the eastern part of the Island, the District of Larnaca (DL) which is about $40 \mathrm{~km}$ away from the olive mills of DF on the south and the district of Paphos (DP) which is about $300 \mathrm{~km}$ away from the olive mills of DF and $250 \mathrm{~km}$ from the olive mill of DL on the west.

The sampling durations were for about 4 months from October to January, and every second week, $50 \mathrm{~kg}$ of OOSR and $50 \mathrm{~L}$ of OMW were taken, and the samples were stored in the fridge at $4^{\circ} \mathrm{C}$.

For all the raw materials and prepared samples for composting, the following parameters were measured: moisture, total solids (TSs), total volatile solids (TVSs), ash, $\mathrm{pH}$ value, electronic conductivity (EC), salinity, chemical oxygen demand $(\mathrm{COD})$, biological oxygen demand $\left(\mathrm{BOD}_{5}\right)$, total organic carbon (TOC), organic matter $(\mathrm{OM})$, total phosphorous $\left(\mathrm{P}_{2} \mathrm{O}_{5}\right), \mathrm{Cl}_{2}$, total kjeldahl nitrogen (TKN), $\mathrm{C} / \mathrm{N}$ ratio, $\mathrm{C} / \mathrm{P}$ ratio, $\mathrm{COD} / \mathrm{BOD}_{5}$ ratio, fats and oils, and $\mathrm{Cl}_{2}$ [59-62]. The total phenolic compounds was determined colorimetrically at $725 \mathrm{~nm}$ on a Shimadzu UV 1240 spectrophotometer using the Folin-Ciocalteau reagent according to the procedures described in detail elsewhere $[9,63]$. Caffeic acid was used as a standard to quantify the concentration of phenols in OMW. Humic substances were extracted $[61,64]$ according to the following scheme: $2.5 \mathrm{~g}$ of sample were shaken for $24 \mathrm{~h}$ in ambient temperature using $100 \mathrm{~mL}$ of $\mathrm{NaOH} 0.5 \mathrm{~N}$. Suspensions were filtered through whatman no. 1 filter paper. Then, the filtrate was dried at $80^{\circ} \mathrm{C}$. The E4/E6 ratio which indicates the characterization of the humics (if the substrate is characterized as humic or fulvic acids) were determined after the extraction of the samples with $\mathrm{NaHCO}_{3} 0.05 \mathrm{~N}(1: 10)$ in 465 and $665 \mathrm{~nm}$ as described by Schnitzer [64] and Zorpas et al. [61]. Lignin and cellulose were determined by a digestion technique of the samples with $72 \%$ sulphuric acid according to Zorpas et al. [61]. Total proteins and sugars were determined using colorimetric method as proposed by Gaudy [65]. The analysis of sodium, magnesium, potassium and calcium content, specific weight, porosity, and other extraction substances were determined according to Handbook of Reference Methods for Soil Analysis [66].

2.3. Experimental Procedure. The OMW from each district (DF, DL, and DP) was subjected to Fenton oxidation treatment (Figure 1). The oxidation was carried out batchwise at $25^{\circ} \mathrm{C}$ in an agitated $(200 \mathrm{rpm})$ temperature and $\mathrm{pH}$ controlled glass reactor of $1 \mathrm{~L}$ capacity for $4 \mathrm{~h}$. First, the wastewater sample was diluted, if necessary. Next, $\mathrm{H}_{2} \mathrm{SO}_{4}$ (98\%) and Fenton reagent were added. As a ferrous salt, $\mathrm{FeSO}_{4} \cdot 7 \mathrm{H}_{2} \mathrm{O}$ was used, and the hydrogen peroxide was of $30 \%$ concentration. After oxidation, vigorous stirring, neutralization with lime, coagulation with a weak anionic polyelectrolyte (2540 Praestol, 0.1\%), and flocculation in a jar test apparatus, the sample was filtered, and the supernatant liquid was analyzed in terms of COD.

The treated olive mill wastewater (TOMW) is the result of the Fenton oxidation treatment which was mixed with the OOSR for further treatment using the composting methods. Two several compost systems according to the following scheme:

$$
\begin{aligned}
& \text { CS1A: OOSRF + OMWF, } \\
& \text { CS1B: OOSRF + TOMWF, } \\
& \text { CS2A1: OOSRF + OMWF, } \\
& \text { CS2B1: OOSRF + TOMWF, }
\end{aligned}
$$

where F referred to the wastes produced from Famagusta's olive mill.

After the treatment of OMW with Fenton treatment, the treated olive mill wastewater (TOMW) with the produced sludges from the Fenton process were proceed for further treatment in two different systems (Figure 1): (i) in lagooning for physical evaporation and with typical red beds and (ii) with cocomposting with OOSR. The amount added to the system was equal with the final moisture of $60 \pm 5 \%$. For the composting of the OOSR with the TOMW, two different systems were used. First, we add to the systems the OOSR and then the TOMW. The amount added to the system was equal with the final moisture of $60 \pm 5 \%$.

(a) Compost System 1 (CS1): a typical windrow system of $6 \mathrm{~m}$ length and $1.5 \mathrm{~m}$ height. The samples were aerated using an aerated air force. The samples were aerated using an aerated air force (oxygen concentration range in the reactor was between $5-$ $8 \%$ ). The temperature (reach from $35^{\circ} \mathrm{C}$ to $45^{\circ} \mathrm{C}$ in the surface and from $65^{\circ} \mathrm{C}$ to $75^{\circ} \mathrm{C}$ in the centre) was monitored by the air and the mechanical stir of the windrow every 7-10 days. The moisture was around $60 \pm 5 \%$. Any time that the moisture was less than $40 \%$ in the surfaces, the windrow were stirred, and a treated liquid waste was added. The amount added to the system was equal with the final moisture of $60 \pm 5 \%$.

(b) Compost System 2 (CS2): an in-vessel reactor of $1 \mathrm{~m}^{3}$ active volume $[17,19,67]$. The thermophilic phase in the reactor lasted $15 \mathrm{~d}$. The temperature in the center of the reactor was about $60^{\circ} \mathrm{C}-65^{\circ} \mathrm{C}$ and the moisture percentage between $60 \pm 5 \%$. The samples were aerated using an aerated air force (oxygen concentration range in the reactor was between 5-8\%). A temperature indicator controller was controlling the operation of the fan in order to maintain the temperature at about $60^{\circ} \mathrm{C}$, according to the following principle: minimum air flow $\left(2.3 \mathrm{~m}^{3}\right.$ per $\mathrm{m}^{3}$ active volume) was provided at low temperature $\left(<30^{\circ} \mathrm{C}\right)$, and maximum air flow $\left(28 \mathrm{~m}^{3}\right.$ per $\mathrm{m}^{3}$ active volume was provided at high temperature 


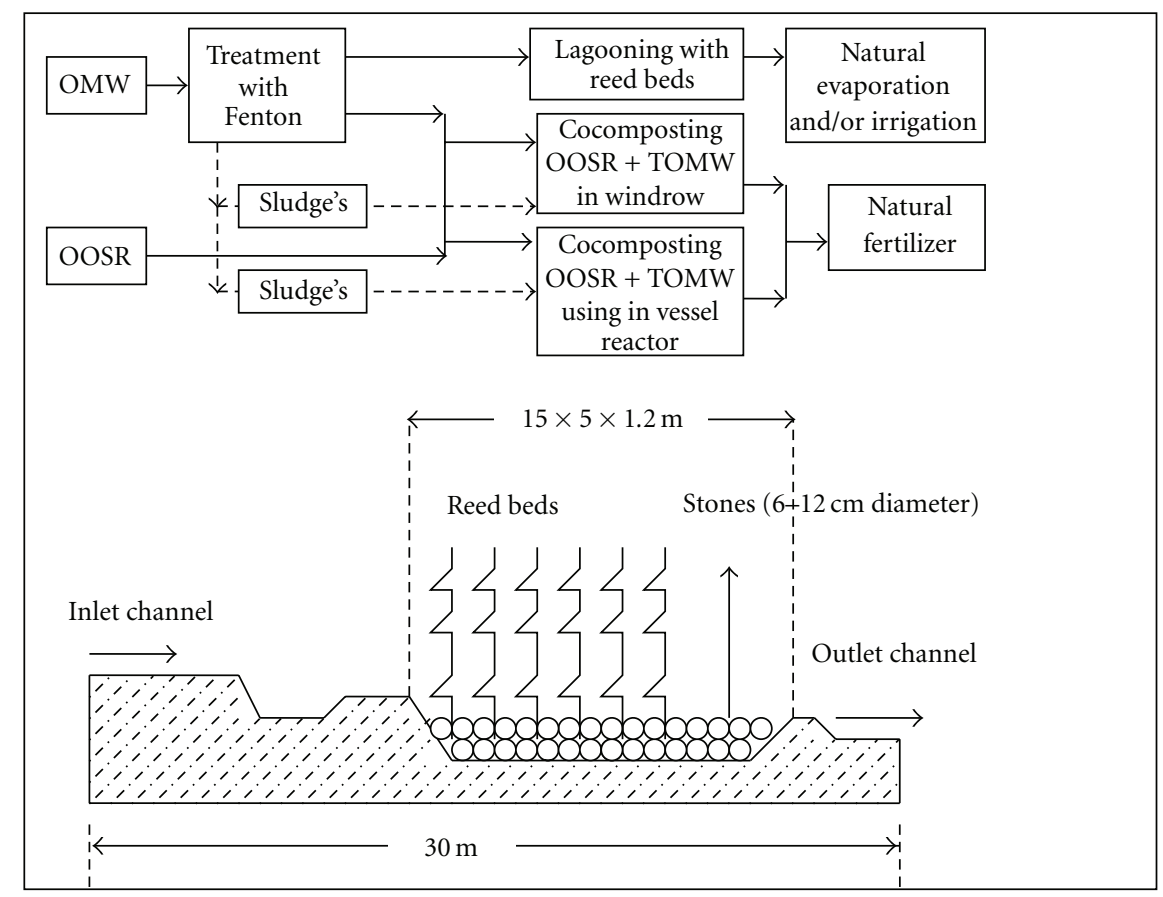

FIGURE 1: Flowchart of the process method with the profile view of reed bed section.

$\left(>60^{\circ} \mathrm{C}\right)$. The minimum airflow corresponds to the minimum oxygen demand for the microorganisms and the maximum to the necessary air for cooling. After the thermophilic period, in which the organic material was biodegraded, the compost was piled to an enclosed package, where it remained for about four months to mature.

The fundamental principle of a cocomposting system is the biodegradation of the organic matter through exothermic aerobic bioreactions which take place in the thermophilic region with the simultaneous evaporation of the moisture of the wastewater due to the release of thermal energy [68]. As a critical parameters for the growth of microorganisms and bioreactions are the oxygen demand, the moisture (which must be in the range of $60 \pm 5 \%$ ), the temperature (which must be retained between $60^{\circ} \mathrm{C}-65^{\circ} \mathrm{C}$ ), and the carbon/nitrogen $(\mathrm{C} / \mathrm{N})$ ratio. After the thermophilic period in which the organic material was biodegraded, the compost was piled to an enclosed package, where it remained for about 3 months to mature.

In order to implement further treatment of the TOMW, all the quantities that remained from the oxidation process was passed then from horizontals bounds with $P$. australis (as indicated from Figure 1).

Seed germination and root length test were performed on water extracts obtained by mixing $10 \mathrm{~g}$ of each sample with $20 \mathrm{~mL}$ of distilled water (DDW) for $2 \mathrm{~h}$. Suspensions were centrifuged at $5000 \mathrm{rpm}$ for $30 \mathrm{~min}$ before being filtered through Whatman no. 1 filter paper. $10 \mathrm{~mL}$ of each test solution was pipetted into a sterilized plastic petri dish. Also, one blank with only DDW was carried out. Twenty lettuce seed were placed in each petri dish and incubated at $22^{\circ} \mathrm{C}$ in the dark for $7 \mathrm{~d}$. The Germination Index (GI) was calculated according to the following formula, [39, 69]:

$$
\mathrm{GI}=\frac{(\% \mathrm{G})(\% \mathrm{~L})}{100},
$$

where $\% \mathrm{G}$ is the grow index,

$$
\% \mathrm{~L}(\text { Root Length })=\frac{(\text { Root Length of Treatment })}{(\text { Root Length of Control })} * 100 .
$$

It is important to know that if the $0<\mathrm{GI}<26$, the substrate is characterized as very phytotoxic, $27<$ GI $<66$, the substrate is characterized as phytotoxic, $67<\mathrm{GI}<100$, the substrate is characterized as nonphytotoxic and if the GI $>101$, then the substrate is characterized as phytonutrient $[17,19]$.

2.4. Controlling Parameters Analysis. The aim of the experimental procedure was to determine the influence of some basic process parameters on the effectiveness of the oxidation treatment in terms of \%COD removal from the OMW. These parameters are dilution of wastewater, heptahydrated ferrous sulphate concentration, hydrogen peroxide concentration, and sulphuric acid concentration. These parameters are referred to as "controlling parameters" of the system. The effect of the controlling parameters on the optimization parameter was estimated by performing a 24 factorial experiment. In general, by using a $2^{n}$ factorial design, $n$ controlling parameters interrelate to an optimization parameter through an appropriate linear model. Their significance can also be estimated and assessed $[69,70]$. Then, most significant 
variables are altered stepwise, aiming at the determination of the optimal experimental conditions. The levels of the controlling parameters are given in Table 1. The experimental area of the factorial design was predetermined in previous preliminary trials. In the 24 factorial designs, 16 experiments were carried out. Four extra experiments in the centre of the design (level 0) were also conducted for statistical purposes. Each experiment was repeated three times, and the results presented are the mean values.

2.5. Statistical Analysis. Statistical analysis was carried out using the Microsoft Excel 2010.

\section{Results and Discussion}

The results obtained indicated that OMW under investigation is characterized by its extremely high content of organic compounds, which is reflected by the high values of $\mathrm{BOD}$, COD, and TOC. Tables 2 and 3 present the physicochemical characteristics of the OMW and the OOSR from the three several olive mills. As indicated in Table 2, the COD and the $\mathrm{BOD}_{5}$ are considered very high which causes serious environmental problems [8-10]. The higher COD presented in the OMW-DL which is $127.4 \pm 36.3 \mathrm{mg} \mathrm{L}^{-1}$, followed by the OMW-DP which is at $122.9 \pm 34.5 \mathrm{mg} \mathrm{L}^{-1}$ and the OMWDF with COD at $118.3 \pm 32.1 \mathrm{mg} \mathrm{L}^{-1}$. The total humics is considered to be very low (less than $1.4 \mathrm{mg} \mathrm{L}^{-1}$ ), while the $\mathrm{E} 4 / \mathrm{E} 6$ is below 5. The E4/E6 ratio shows the characterization of humic materials. As the E4/E6 ratio is below 5, the samples are characterized as humic acid (whereas if the ratio is above 5 , the sample is characterized as fulvic acid), [19, 61, 64]. The COD/BOD ratio ranges from $2.98: 1$ to $4.05: 1$, which indicates the presence of poor biodegradable organic compounds and/or toxic ones [3]. The GI is presented to be less than 26 , and the substrate is characterized as very phytotoxic either for the OMW and for the OOSR. The $\mathrm{C} / \mathrm{N}$ ratio both of the substrates (OMW and OOSR) is considered to be at very satisfactory levels for composting process. The variation of the EC is due to the different quality of the water used in the production line. Similar results from the characteristic of OMW from Greece are found in Stoller [9]. El Hajjouji et al. [71] mention that the chemical characteristics of the OMW from Morocco is for COD $19.2 \mathrm{gO}_{2} \mathrm{~L}^{-1}, \mathrm{pH}$ is 5 , and total phenols is at $1.67 \mathrm{mg} \mathrm{L}^{-1}$. El-Gohary et al. [3] mention that the COD, TOC, and BOD values, ranged from 102900 to $207300 \mathrm{mg} \mathrm{O}_{2} \mathrm{~L}^{-1}$, from 30000 to 93000 and from 78528 to $135400 \mathrm{mg} \mathrm{O}_{2} \mathrm{~L}^{-1}$, respectively, form OMW.

Table 4 presents COD removal efficiency results of the factorial experiments in all the OMW.

Fenton processes are suitable to treat a wide variety of effluents irrespective of their concentration and origin and are characterised by their simple and versatile operation. As olive oil manufacturing industries are usually small plants with a low, seasonal wastewater flow, a small Fenton unit would suffice to cope efficiently with the effluents produced. Rivas et al. [72] estimated that OMW treatment $\left(15 \mathrm{mg} \mathrm{L}^{-1}\right.$ of inlet COD and $80-90 \%$ COD reduction achieved in residence times between 1 and $8 \mathrm{~h}$ depending on the operating conditions employed) by Fenton's reagent would cost USD $3.2 /\left(\mathrm{m}^{3}\right.$ of wastewater treated and $\mathrm{mg} \mathrm{L}^{-1}$ of COD removed). This value is greater than that of the conventional biological treatment of OME by about an order of magnitude, since $\mathrm{H}_{2} \mathrm{O}_{2}$ consumption comprises a significant fraction of the operating costs. In this respect, studies are needed to optimise the dosage of the Fenton's components used, thus avoiding waste of costly chemicals [10].

From this data, a mathematical model was constructed. Its adequacy was checked by the Fisher criterion. According to the latter, the following ratio should follow the $F$-distribution with level of importance $p=5 \%$ :

$$
F=\frac{S_{\mathrm{ad}}^{2}}{S_{Y}^{2}},
$$

where $S_{Y}^{2}$ is the standard deviation and $S_{\mathrm{ad}}^{2}$ sthe following equation:

$$
S_{\mathrm{ad}}^{2}=\frac{\sum_{i=1}^{N}\left(Y_{i}-\hat{Y}_{i}\right)^{2}}{f},
$$

where $Y_{i}$ is the experimental $i$ value, $\hat{Y}_{i}$ is the estimated $I$ value from the model determined, $f$ is the number of degrees of freedom, and $N$ is the number of trials.

As far as the determination of statistically important parameters is concerned, the procedure mentioned below was followed. The coefficient deviation is defined as

$$
S^{2}\left(b_{j}\right)=\frac{S_{Y}^{2}}{N},
$$

where $N$ is the number of trials.

The importance of the coefficient was checked by

$$
t=\frac{\left|b_{j}\right|}{S\left(b_{j}\right)},
$$

where $b_{j}$ is the $j$ linear coefficient. " $t$ " should follow the Student distribution for importance level $p=5 \%$ and degrees of freedom those of the deviation $S^{2}(Y)$. After the mathematical model construction and the determination of statistically important parameters, an effort to find the optimum conditions for the effectiveness of the Fenton oxidation treatment of wood-processing industry wastewater was made. This was performed through a steepest ascent method [69].

El-Gohary et al. [3] investigated a similar system for the treatment of the OMW with Fenton and anaerobic treatment (USBR: upflow anaerobic reactor). The use of an integrated treatment scheme consisting of wet hydrogen peroxide catalytic oxidation (WHPCO) followed by twostage upflow anaerobic sludge blanket (UASB) reactor $(10: 1$ each) for the treatment of olive mill wastewater. The diluted wastewater $(1: 1)$ was pretreated according to El-Gohary et al. [3] using Fenton's reaction. Optimum operating conditions namely, $\mathrm{pH}, \mathrm{H}_{2} \mathrm{O}_{2}$ dose, $\mathrm{Fe}^{+2}, \mathrm{COD}: \mathrm{H}_{2} \mathrm{O}_{2}$ ratio, 
TABLE 1: Controlling parameters and their levels in the factorial experiment.

\begin{tabular}{lccccc}
\hline & \multicolumn{2}{c}{ Controlling parameters } & \multicolumn{2}{c}{ Variation intervals } \\
& Units & $\begin{array}{c}\text { Representation } \\
\text { as }\end{array}$ & $\begin{array}{c}+1 \\
\text { Level }\end{array}$ & $\begin{array}{c}0 \\
\text { Level }\end{array}$ & $\begin{array}{c}-1 \\
\text { Level }\end{array}$ \\
\hline Wastewater dilution & $\%$ & $X_{1}$ & 0 & 50 & 100 \\
$\mathrm{FeSO}_{4} \cdot 7 \mathrm{H}_{2} \mathrm{O}$ addition & $\mathrm{g} \mathrm{L}^{-1}$ & 4.0 & 5.0 & 6.0 \\
$\mathrm{H}_{2} \mathrm{O}_{2}(30 \%)$ addition & $\mathrm{mL} \mathrm{L}^{-1}$ & $X_{3}$ & 2.0 & 2.50 & 3.50 \\
$\mathrm{H}_{2} \mathrm{SO}_{4}(98 \%)$ addition & $\mathrm{mL} \mathrm{L}^{-1}$ & $X_{4}$ & 0.50 & 0.25 & 0.75 \\
\hline
\end{tabular}

TABLE 2: Composition of the olive mill wastewater.

\begin{tabular}{|c|c|c|c|}
\hline Characteristics & OMW-DF & OMW-DL & OMW-DP \\
\hline Total solids (TS), \% & $6.33 \pm 1.81$ & $6.09 \pm 1.05$ & $6.59 \pm 0.98$ \\
\hline Total volatile solids, $\%$ of TS & $90.36 \pm 3.31$ & $91.93 \pm 4.15$ & $88.12 \pm 3.69$ \\
\hline Total organic carbon content, $\%$ of TS & $62.71 \pm 6.27$ & $60.17 \pm 5.99$ & $64.30 \pm 7.12$ \\
\hline Total kjeldahl nitrogen, $\%$ of TS & $1.28 \pm 0.17$ & $1.31 \pm 0.20$ & $1.25 \pm 0.19$ \\
\hline Total phosphorous as $\mathrm{P}_{2} \mathrm{O}_{5}, \%$ of TS & $0.84 \pm 0.17$ & $0.92 \pm 0.11$ & $0.88 \pm 0.11$ \\
\hline Total phenolic compounds $\mathrm{g} \mathrm{L}^{-1}$ & $8.71 \pm 0.51$ & $9.02 \pm 0.39$ & $490 \pm 0.28$ \\
\hline $\mathrm{pH}$ & $5.66 \pm 0.3$ & $5.52 \pm 0.4$ & $5.58 \pm 0.3$ \\
\hline $\mathrm{EC} \mathrm{mS} \mathrm{cm}^{-1}$ & $2120 \pm 57$ & $1984 \pm 33$ & $1277 \pm 12$ \\
\hline Salinity $\mathrm{mg} \mathrm{L}^{-1} \mathrm{CaCO}_{3}$ & $1058 \pm 91$ & $901 \pm 28$ & $645 \pm 48$ \\
\hline $\mathrm{BOD}_{5}, \mathrm{gL}^{-1}$ & $17.3 \pm 5.5$ & $20.1 \pm 9.7$ & $13.7 \pm 3.4$ \\
\hline COD, $\mathrm{g} \mathrm{L}^{-1}$ & $70.1 \pm 12.3$ & $57.4 \pm 6.3$ & $45.9 \pm 4.5$ \\
\hline $\mathrm{COD} / \mathrm{BOD}_{5}$ ratio & $4.05 \pm 0.91$ & $3.01 \pm 0.87$ & $2.98 \pm 0.92$ \\
\hline Ash, \% of TS & $9.71 \pm 3.21$ & $8.99 \pm 2.18$ & $9.25 \pm 3.05$ \\
\hline $\mathrm{C} / \mathrm{N}$ ratio & $52.25 \pm 5.24$ & $45.93 \pm 4.15$ & $51.44 \pm 6.02$ \\
\hline $\mathrm{C} / \mathrm{P}$ ratio & $74.65 \pm 3.81$ & $65.40 \pm 6.17$ & $73.68 \pm 4.15$ \\
\hline Specific weight, $\mathrm{gr} \mathrm{cm}^{-3}$ & $1.048 \pm 0.033$ & $1.057 \pm 0.029$ & $1.022 \pm 0.041$ \\
\hline Fats and oils, $\mathrm{mg} \mathrm{L}^{-1}$ & $1.46 \pm 0.20$ & $1.45 \pm 0.22$ & $6307.5 \pm 279$ \\
\hline Germination index, \% & $18 \pm 5$ & $16 \pm 7$ & $11 \pm 6$ \\
\hline Humics, $\%$ & $0.94 \pm 0.12$ & $1.04 \pm 0.27$ & $0.89 \pm 0.21$ \\
\hline $\mathrm{E} 4 / \mathrm{E} 6$ & $1.34 \pm 0.03$ & $1.53 \pm 0.05$ & $1.44 \pm 0.03$ \\
\hline $\mathrm{K} \mathrm{mg} \mathrm{L}^{-1}$ & $3.1 \pm 0.45$ & $2.87 \pm 0.50$ & $2.17 \pm 0.21$ \\
\hline Ca mg L L & $271.4 \pm 14.1$ & $248.7 \pm 16.9$ & $210.6 \pm 12.2$ \\
\hline $\mathrm{Mg} \mathrm{mg} \mathrm{L}^{-1}$ & $32.8 \pm 5.3$ & $28.2 \pm 4.7$ & $22.9 \pm 6.1$ \\
\hline $\mathrm{Na} \mathrm{mg} \mathrm{L}{ }^{-1}$ & $344.3 \pm 15.1$ & $322.6 \pm 16.9$ & $209.1 \pm 17.2$ \\
\hline $\mathrm{Cl}_{2} \mathrm{mgL}^{-1}$ & $401.4 \pm 51.4$ & $367.8 \pm 41.9$ & $212.3 \pm 24.7$ \\
\hline
\end{tabular}

TS: total solids; EC: electronic conductivity; COD: chemical oxygen demand; BOD: biological oxygen demand.

and $\mathrm{Fe}^{+2}: \mathrm{H}_{2} \mathrm{O}_{2}$ ratio, were determined. The UASB reactor was fed continuously with the pretreated wastewater. The final results according to El-Gohary et al. [3] indicated that the quality of the treated effluent was quite satisfactory. Residual concentrations of $\mathrm{COD}, \mathrm{BOD}_{5}, \mathrm{TOC}$, TSS, and oil and grease, and total phenols were 4055, 2029, 2050, 279, and $97 \mathrm{mg} \mathrm{L}^{-1}$. Corresponding removal were $91 \%, 85 \%, 86 \%$, $99 \%$, and $95 \%$, respectively. The degradation of polyphenolic compounds by Fenton's reaction was ranged from $80 \%$ to 95\%. These results according to El-Gohary et al. [3] indicate that Fenton's reaction is very efficient as a pretreatment step for degradation of polyphenolic compounds from OMW. Therefore, sludge produced from OMW treatment and solid residues of olive mills could be converted to valuable products [3].
The TOMWF has been proceeding in cocomposting with the OOSR from the same olive mill in two several compost systems as described above.

Table 5 shows the characterisation of the final product after $120 \mathrm{~d}$ of maturity. It was obvious that the B1 sample of CS2 was presented with better characteristics than the other final products. The compost quality with respect to agricultural use depends on its inorganic nitrogen content. It should not exceed $10 \%$ of the total nitrogen, and the ammonia content should be less than the $0.04 \%$ of the dry matter [73]. The final total concentration did not exceed the above limit, rendering the compost to be a good soil conditioner.

Phenolic compounds commonly found in OME can be classified in three major families as follows: 
TABle 3: Composition of the olive oil solid residue.

\begin{tabular}{|c|c|c|c|}
\hline Characteristics & OOSR-DF & OOSR-DL & OOSR-DP \\
\hline Moisture & $48.71 \pm 2.01$ & $50.12 \pm 1.92$ & $62.1 \pm 2.12$ \\
\hline Total solids (TS), \% & $86.00 \pm 3.33$ & $85.34 \pm 4.01$ & $77.98 \pm 6.71$ \\
\hline Total organic carbon content, $\%$ of TS & $51.45 \pm 4.48$ & $46.79 \pm 3.32$ & $47.12 \pm 3.61$ \\
\hline Total kjeldahl nitrogen, $\%$ of TS & $1.06 \pm 0.15$ & $1.12 \pm 0.07$ & $0.79 \pm 0.10$ \\
\hline Total phosphorous as $\mathrm{P}_{2} \mathrm{O}_{5}, \%$ of TS & $0.11 \pm 0.01$ & $0.13 \pm 0.01$ & $0.07 \pm 0.01$ \\
\hline Fats and oils, $\%$ of TS & $4.65 \pm 1.09$ & $4.89 \pm 1.21$ & $6.02 \pm 0.93$ \\
\hline Total proteins, $\%$ of TS & $3.29 \pm 0.12$ & $3.97 \pm 0.19$ & $2.43 \pm 0.19$ \\
\hline Total sugars, $\%$ of TS & $1.07 \pm 0.09$ & $1.12 \pm 0.11$ & $0.96 \pm 0.04$ \\
\hline Cellulose, $\%$ of TS & $22.27 \pm 0.44$ & $19.31 \pm 0.96$ & $16.30 \pm 0.47$ \\
\hline Hemicellulose, \% of TS & $16.57 \pm 0.94$ & $14.90 \pm 0.78$ & $9.45 \pm 1.02$ \\
\hline Ash, $\%$ of TS & $3.65 \pm 0.25$ & $4.01 \pm 0.44$ & $3.12 \pm 0.17$ \\
\hline Other extraction substances, $\%$ of TS & $8.38 \pm 0.35$ & $9.45 \pm 0.59$ & $7.12 \pm 0.28$ \\
\hline Lignin, $\%$ of TS & $11.95 \pm 0.45$ & $14.41 \pm 0.87$ & $9.39 \pm 0.68$ \\
\hline Potassium as $\mathrm{K}_{2} \mathrm{O}, \%$ of TS & $0.83 \pm 0.11$ & $0.91 \pm 0.07$ & $0.87 \pm 0.11$ \\
\hline Calcium content, $\%$ of TS & $0.72 \pm 0.08$ & $0.67 \pm 0.03$ & $0.65 \pm 0.04$ \\
\hline $\mathrm{C} / \mathrm{N}$ ratio & $48.53 \pm 5.03$ & $41.77 \pm 3.97$ & $59.64 \pm 4.45$ \\
\hline $\mathrm{C} / \mathrm{P}$ ratio & $467.72 \pm 42.1$ & $359.92 \pm 53.9$ & $673.14 \pm 79.98$ \\
\hline Specific weight, $\mathrm{gr} \mathrm{cm}^{-3}$ & $1.09 \pm 0.02$ & $1.12 \pm 0.08$ & $1.35 \pm 0.04$ \\
\hline porosity, \% & $52.4 \pm 5.5$ & $49.3 \pm 4.9$ & $28.6 \pm 6.6$ \\
\hline Germination index, $\%$ & $17 \pm 3$ & $21 \pm 5$ & $16 \pm 9$ \\
\hline Humics, \% & $1.03 \pm 0.08$ & $1.18 \pm 0.31$ & $0.92 \pm 0.30$ \\
\hline E4/E6 ratio & $1.00 \pm 0.05$ & $0.95 \pm 0.07$ & $1.10 \pm 0.13$ \\
\hline
\end{tabular}

TS: total solids.

TABLe 4: Percent COD removal efficiency results of the factorial experiment.

\begin{tabular}{lccccccc}
\hline Trial & $X_{1}$ & $X_{2}$ & $X_{3}$ & $X_{4}$ & \% COD efficiency in OMW-DF & \% COD efficiency in OMW-DL & \% COD efficiency in OMW-DP \\
\hline$(1)$ & + & + & + & + & 67.06 & 64.90 & 63.65 \\
$(2)$ & - & + & + & + & 60.14 & 60.92 & 59.75 \\
$(3)$ & + & - & + & + & 67.68 & 65.52 & 64.26 \\
$(4)$ & - & - & + & + & 54.67 & 55.38 & 54.32 \\
$(5)$ & + & + & - & + & 64.37 & 65.21 & 63.95 \\
$(6)$ & - & + & - & + & 61.37 & 62.17 & 60.97 \\
$(7)$ & + & - & - & + & 65.53 & 66.38 & 65.10 \\
$(8)$ & - & - & - & + & 69.53 & 70.39 & 68.10 \\
$(9)$ & + & + & + & - & 69.37 & 68.22 & 64.95 \\
$(10)$ & - & + & + & - & 63.76 & 64.58 & 63.34 \\
$(11)$ & + & - & + & - & 64.83 & 65.68 & 64.41 \\
$(12)$ & - & - & + & - & 62.99 & 63.80 & 62.58 \\
$(13)$ & + & + & - & - & 64.99 & 65.83 & 64.57 \\
$(14)$ & - & + & - & - & 61.83 & 62.63 & 61.43 \\
$(15)$ & + & - & - & - & 66.45 & 67.31 & 66.02 \\
$(16)$ & - & - & - & - & 64.30 & 65.13 & 63.88 \\
$(17)$ & 0 & 0 & 0 & 0 & 63.37 & 64.19 & 62.96 \\
$(18)$ & 0 & 0 & 0 & 0 & 63.91 & 64.74 & 63.50 \\
$(19)$ & 0 & 0 & 0 & 0 & 63.68 & 65.21 & 63.27 \\
$(20)$ & 0 & 0 & 0 & 0 & 64.37 & & \\
\hline
\end{tabular}

COD: chemical oxygen demand. 
TABle 5: Physicochemical characteristics of mature compost (120d).

\begin{tabular}{|c|c|c|c|c|}
\hline Parameters & CS1A & CS1A1 & CS2B & CS2B1 \\
\hline Moisture \% & $32.1 \pm 5.03$ & $26.8 \pm 2.35$ & $28.2 \pm 1.99$ & $22.5 \pm 2.19$ \\
\hline $\mathrm{pH}$ & $7.2 \pm 0.05$ & $7.7 \pm 0.03$ & $7.7 \pm 0.03$ & $7.6 \pm 0.01$ \\
\hline Ash, $\%$ of dry matter & $25.85 \pm 1.87$ & $29.68 \pm 1.33$ & $28.81 \pm 1.66$ & $27.10 \pm 1.51$ \\
\hline Organic matter, $\%$ of dry matter & $74.15 \pm 3.09$ & $70.32 \pm 4.12$ & $71.19 \pm 2.99$ & $72.90 \pm 1.97$ \\
\hline Total organic carbon, $\%$ of dry matter & $40.7 \pm 4.31$ & $37.27 \pm 3.16$ & $40.58 \pm 3.01$ & $39.01 \pm 2.19$ \\
\hline Total kjeldahl nitrogen, $\%$ & $1.13 \pm 0.16$ & $1.33 \pm 0.22$ & $1.30 \pm 0.14$ & $1.44 \pm 0.11$ \\
\hline Total phosphorous $\%$ & $0.45 \pm 0.11$ & $0.55 \pm 0.05$ & $0.61 \pm 0.12$ & $0.52 \pm 0.07$ \\
\hline $\mathrm{C} / \mathrm{N}$ ratio & $36.01 \pm 3.41$ & $28.02 \pm 2.13$ & $31.22 \pm 3.04$ & $27.09 \pm 2.21$ \\
\hline $\mathrm{C} / \mathrm{P}$ ratio & $90.44 \pm 12.91$ & $67.76 \pm 7.01$ & $66.52 \pm 9.18$ & $75.01 \pm 5.66$ \\
\hline Humic substances, $\%$ of dry matter & $5.84 \pm 1.09$ & $6.35 \pm 0.97$ & $7.04 \pm 1.13$ & $7.15 \pm 0.88$ \\
\hline Total phenolic compounds, $\mathrm{mg} / \mathrm{kg}$ & $212 \pm 34$ & $192 \pm 23$ & $188 \pm 51$ & $173 \pm 19$ \\
\hline Germination index & $124 \pm 21$ & $138 \pm 12$ & $177 \pm 19$ & $201 \pm 9$ \\
\hline Grow index \% & $73 \pm 5$ & $77 \pm 6$ & $77 \pm 10$ & $92 \pm 3$ \\
\hline
\end{tabular}

(i) cinnamic acid $\left(\mathrm{C}_{6} \mathrm{H}_{5} \mathrm{CH}=\mathrm{CHCOOH}\right)$ derivatives such as coumaric, caffeic, and ferulic acids,

(ii) benzoic acid $\left(\mathrm{C}_{6} \mathrm{H}_{5} \mathrm{COOH}\right)$ derivatives such as vanillic, gallic, veratric, syringic, protocatechuic, and hydroxybenxoic acids,

(iii) tyrosol and related compounds such as hydroxytyrosol and hydroxyphenylacetic acid.

Herrera et al. [74] applied Fenton and photo-Fenton with simulated solar light, and the efficiency was $60 \%$ and $100 \%$ TOC removal after $25 \mathrm{~h}$ of Fenton and photo-Fenton, respectively, with $10 \mathrm{mM} \mathrm{H}_{2} \mathrm{O}_{2}$ added stepwise and $2.6 \mathrm{mM}$ $\mathrm{Fe}^{3+}$ (Initial pCA $=3.9 \mathrm{mM}$ ). Several recent studies [7581] have dealt with the treatment of synthetic solutions containing one or more of the above compounds by means of $\mathrm{AOP}$, and all of them indicated a strong decrease of the initial amount.

Figure 2 shows the variation of $\mathrm{pH}, \mathrm{GI}, \mathrm{C} / \mathrm{N}$ ratio and humics formations. $\mathrm{pH}$ is a parameter which greatly affects the composting process. The optimum $\mathrm{pH}$ values are 6-7.5 for bacterial development, while fungi prefer an environment in the range of $5.5-8.0[17,20,73,82]$. Usually during composting, the $\mathrm{pH}$ values are initially low because of volatile acids production, then the $\mathrm{pH}$ increases (due to the $\mathrm{NH}_{4}-\mathrm{N}$ ), and in the final stage of composting, a decrease in the $\mathrm{pH}$ is expected [21]. Actually, $\mathrm{pH}$ higher than 8.5 joined temperatures in the thermophilic range favors ammonification that may contribute to the unpleasant odours' emissions from composting process.

As shown in Figure 2, the $\mathrm{C} / \mathrm{N}$ ratio rapidly decreased during the first $10 \mathrm{~d}$ (for all the samples except for the CS1B which is decreasing until the $25 \mathrm{~d}$ ). The nitrogen is usually affected by the action of the proteolytic bacteria and by the temperature. At high temperatures, the nitrogen is released to the atmosphere, and the $\mathrm{C} / \mathrm{N}$ ratio is increasing. Lower $\mathrm{C} / \mathrm{N}$ ratio increases the loss of nitrogen by leaching (e.g., nitrate mobilization) and ammonia volatilization whereas higher levels necessitate progressively longer composting time as nitrogen becomes the microbial limiting nutrient [83]. It is obvious from Figure 2 that the total nitrogen seemed to increase during $10-20 \mathrm{~d}$. This was caused by a decrease in the substrate carbon resulting from $\mathrm{CO}_{2}$ loss plus the action of the azotobacterial which fix nitrogen from the atmosphere. The microbial biomass mainly consists of protein; therefore, the $\mathrm{C} / \mathrm{N}$-ratio is about $6.25: 1$, and $\mathrm{C}: \mathrm{P}$ ratio is about 100:1 [17]. Assuming that in the composting process about $20 \%$ of the organic carbon is transformed into microbial biomass, then the appropriate initial ratios of $\mathrm{C} / \mathrm{N}$ and $\mathrm{C} / \mathrm{P}$ must be about 30 and 500, respectively. Table 5 shows that the ratio $\mathrm{C} / \mathrm{N}$ is from $27.09 \pm 2.13$ for SC2B1 to $36.01 \pm 3.41$ for SC1A cured compost while the $\mathrm{C} / \mathrm{P}$ ratio is from $66.52 \pm 9.18$ for $\mathrm{SC} 2 \mathrm{~B}$ to $90.44 \pm 12.91$ for SC1A. From Table 5 and Figure 2, it is clear that the quantities of nitrogen are suitable for composting, while the quantities of phosphorous are in satisfactory levels, but an extra addition of phosphorus nutrient is subjected. The $\mathrm{C} / \mathrm{N}$ ratio for this stabilized compost was considered very satisfactory for agricultural use.

$\mathrm{C} / \mathrm{N}$ ratio is used to assess stability and maturity. A composting process results in the fall of $\mathrm{C} / \mathrm{N}$ ratio because of microbial activities (the conservation of nitrogen and the transformation of carbon to $\mathrm{CO}_{2}$ and humic substances). It has been reported that when the $\mathrm{C} / \mathrm{N}$ ratio is less than 20 , the compost will be mature and can be used without any restriction [84]. The ideal $\mathrm{C} / \mathrm{N}$ ratio or well-matured compost is about 10 , which is usually difficult to achieve. A final $\mathrm{C} / \mathrm{N}$ equal to or greater than 30 is thought to inhibit the mineralization of nitrogen and may actually tie up nitrogen from the soil [13].

Germination index is a parameter usually used to characterize the compost products. During the composting process (until the 15th d), the GI was 22-31 due to the fact that compost was immature. The appearance of the phytotoxicity in the first step of the composting process has to do with the decomposition of the organic matter. The immature composts seem to have high phytotoxicity due to the fact that phytotoxic compounds (ammonia, ethylene oxide, low molecular weigh organic acids, or organic pollutants such as phenolic compounds) [19] are produced by microorganisms and also because at the first step of composting, the $\mathrm{pH}$ 


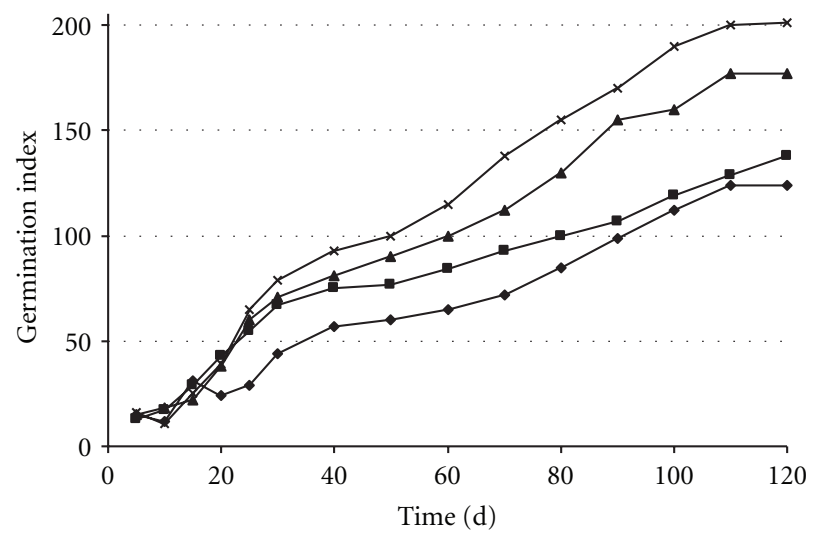

(a)

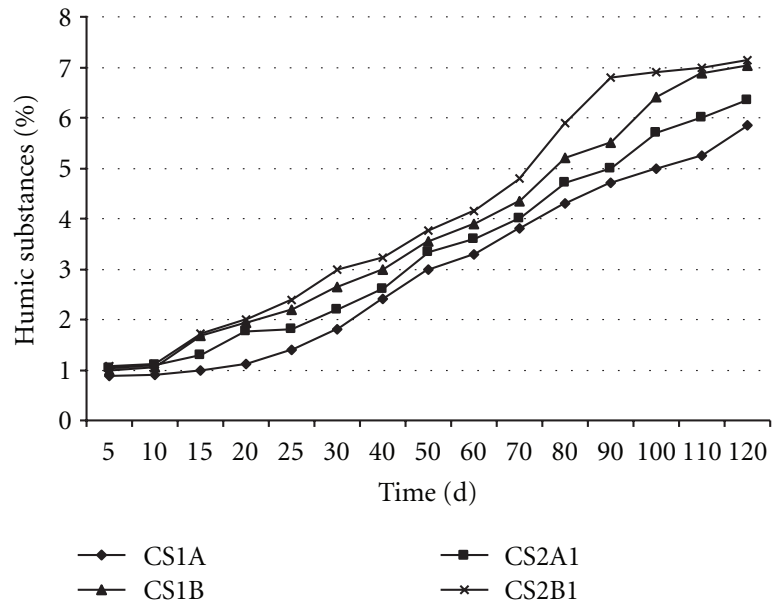

(c)

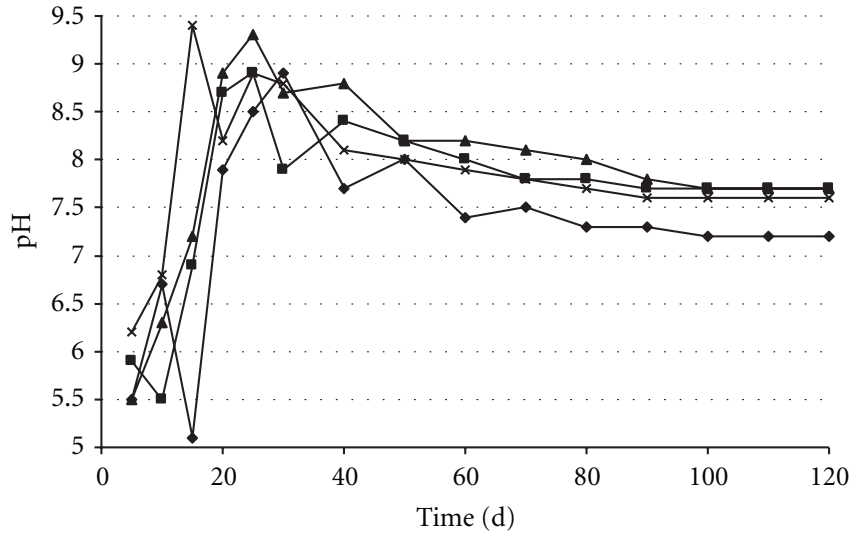

(b)

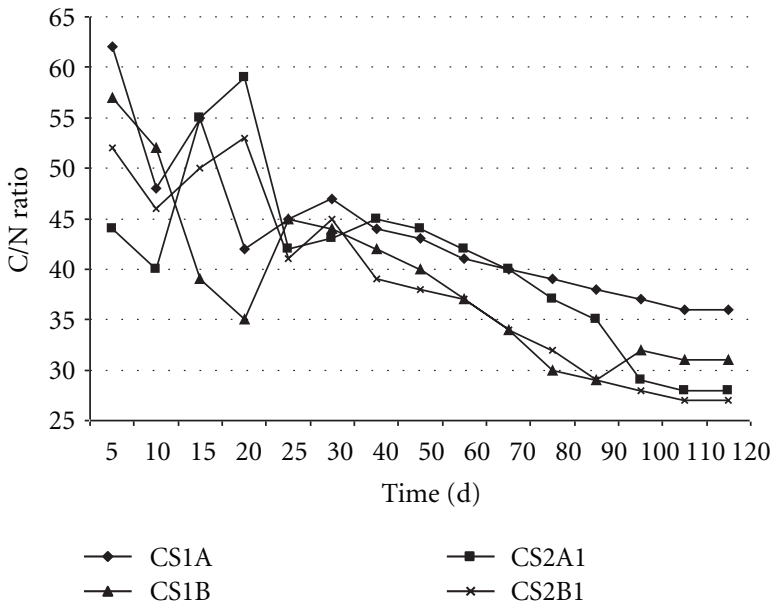

(d)

Figure 2: (a) Germination index during the composting process of the two several compost systems. Refer to Section 2.3 for treatment codes. (b) $\mathrm{pH}$ variation, during the composting process of the two several compost systems. Refer to Section 2.3 for treatment codes. (c) Humic substances variation, during the composting process of the two several compost systems. Refer to Section 2.3 for treatment codes. (d) C/N ratio variation during the composting process of the two several compost systems. Refer to Section 2.3 for treatment codes.

is initially low, due to the acid formation $(\mathrm{pH}<5.5)$ and ammonias $(\mathrm{pH}>8.5)[17,22]$. From the $20-75 \mathrm{~d}$ (which we have the formation of humics, Figure 2), the GI were up to 70 almost for all the samples. Specifically, at $75 \mathrm{~d}$, the GI is $72 \pm 3$ for SC1A, $93 \pm 7$ for SCA1, $112 \pm 13$ for SC2B and $138 \pm 15$ for SC2B1 compost. From Figure 2 it is obvious that it is unable to use the substrate for cultivation before the $80 \mathrm{~d}$ of maturity. The substrate is characterized as nonphytotoxic after $80 \mathrm{~d}$ of maturity for the SC1A, $50 \mathrm{~d}$ of maturity of the SC1A1, $40 \mathrm{~d}$ of maturity of the SC2B, and $30 \mathrm{~d}$ of the SC2B1. It is obvious that the implementation of the control conditions at the first step of composting using an in-vessel reactor promotes a better soil condoner faster than the typical windrow systems. Total humics are presented at satisfactory levels. The GI after $120 \mathrm{~d}$ of composting and maturity is $124 \pm 21$ for SC1A, $138 \pm 12$ for SC1A1, $177 \pm 19$ for SC2B and $201 \pm 9$ for SC2B1, while the humics are presented from $5.84 \pm 1.09 \%$ for the SC1A to $7.15 \pm 0.88 \%$ for the SC2B1.The Grow Index $(\% \mathrm{G})$ at the same time was at $73 \pm 5,77 \pm 6,77 \pm 10,92 \pm 3$ for SC1A, SC1A1, SC2B, SC2B1, respectively.
Comparing the results with other studies caring before, it was found that the GI from pig compost is 160 while from compost from a mixture of pig slurry and wood shavings is up to 217 [85]. According to some other researchers [39], the GI after $150 \mathrm{~d}$ of composting and maturity from sewage sludge compost with zeolites is 147 for oats, 108 for peppers, and 96 for eggplant cultivations. Composting is an effective way for handling biodegradable fraction of waste streams and generating a lucrative product compost. In today's markets, the rapid growth of waste compost calls for a high attention to its product quality. To protect the lands and plants on which the compost is applied, it is also critical to have its quality properly assessed. However, evaluation of the composting product quality has been a challenging task due to the existence of numerous physiochemical and biological indicators and various evaluation standards [13, 86]. Alburquerque et al. [87] exhibited GI values higher than $70 \%$, which indicated a clear detoxification of the initial substrate and was related with the suitable stability and maturity of the AL compost (AL is the main olive mill byproduct in Spain known as "alperujo"). 


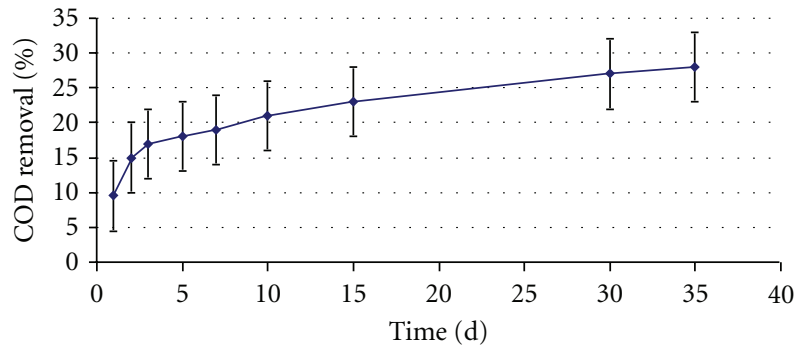

FIGURE 3: COD removal using reed beds.

Figure 3 presents the COD removal from the application of reed beds after the treatment of the OMW with Fenton. The COD is reduced from 10-28\%. Del Bubba et al. [57] mention that the application of reed bed for the olive mill wastewater (OMW) treatment has the ability to reduce COD up to $68.9 \%$, the TKN up to $12.4 \%$, and the total P up to $54.5 \%$

\section{Conclusions}

The solution of the environmental problems caused by the production of olive oil is essential for the future of the olive oil industry. The treatment of liquid wastes produced from olive oil production is still a major challenge facing this industry. The main problem is attributed to its dark colour, high organic content, and toxicity which are due to the presence of phenolic compounds. In this study, a combination of chemical oxidation (by the application of Fenton), reed beds and, composting has been applied for the treatment of the heavy polluted wastewaters from olive mill industries. The following conclusions can be drawn from this study. Firstly, the removal efficiency obtained from the implementation of Fenton indicated a COD removal up to $65 \%$. Secondly, the use of reed bed as tetrially treatment gives additional benefits as the reduction of COD existed up to $28 \%$. Thirdly, the final compost characteristic makes the compost suitable for agricultural requirements and suggests that it can be used as an effective product for plant growth according to the European guidelines [88, 89]. From all the above, it can be concluded that as far as the pollution problems caused by olive oil production are regarded, a solution based on the principles of the clean technology concept could be the detoxification of wastewaters and the composting with the olive oil solid residues.

\section{References}

[1] I. Sabbah, T. Marsook, and S. Basheer, "The effect of pretreatment on anaerobic activity of olive mill wastewater using batch and continuous systems," Process Biochemistry, vol. 39, no. 12, pp. 1947-1951, 2004.

[2] S. Khoufi, F. Aloui, and S. Sayadi, "Treatment of olive oil mill wastewater by combined process electro-Fenton reaction and anaerobic digestion," Water Research, vol. 40, no. 10, pp. 20072016, 2006.

[3] F. A. El-Gohary, M. I. Badawy, M. A. El-Khateeb, and A. S. El-Kalliny, "Integrated treatment of olive mill wastewater
(OMW) by the combination of Fenton's reaction and anaerobic treatment," Journal of Hazardous Materials, vol. 162, no. 2-3, pp. 1536-1541, 2009.

[4] F. Cabrera, R. López, A. Martinez-Bordiú, E. De Dupuy Lome, and J. M. Murillo, "Land treatment of olive oil mill wastewater," International Biodeterioration and Biodegradation, vol. 38, no. 3-4, pp. 215-225, 1996.

[5] P. Cañizares, J. Lobato, R. Paz, M. A. Rodrigo, and C. Sáez, "Advanced oxidation processes for the treatment of olive-oil mills wastewater," Chemosphere, vol. 67, no. 4, pp. 832-838, 2007.

[6] "Agricultural Statistics, (2006)," Department of Statistics and Research, Ministry of Finance. Rebublic of Cyprus, July 2006.

[7] “Imports and Exports Statistics 1985-1999," Department of Statistics and Research, Ministry of Finance, Cyprus, 2000.

[8] M. Gotsi, N. Kalogerakis, E. Psillakis, P. Samaras, and D. Mantzavinos, "Electrochemical oxidation of olive oil mill wastewaters," Water Research, vol. 39, no. 17, pp. 4177-4187, 2005.

[9] M. Stoller, "On the effect of flocculation as pretreatment process and particle size distribution for membrane fouling reduction," Desalination, vol. 240, no. 1-3, pp. 209-217, 2009.

[10] D. Mantzavinos and N. Kalogerakis, "Treatment of olive mill effluents: part I. Organic matter degradation by chemical and biological processes - an overview," Environment International, vol. 31, no. 2, pp. 289-295, 2005.

[11] A. J. Fiestas Ros, "Reuse and complete treatment of vegetable water: current situation and prospects in Spain," in Proceedings of International Conference in Olive Oil Processing Wastewater Treatment Methods, Crete, Greece, 1991.

[12] A. A. Zorpas, A. G. Vlyssides, G. A. Zorpas, P. K. Karlis, and D. Arapoglou, "Impact of thermal treatment on metal in sewage sludge from the Psittalias wastewater treatment plant, Athens, Greece," Journal of Hazardous Materials, vol. 82, no. 3, pp. 291298, 2001.

[13] Y. M. Zhang, G. H. Huang, L. He, and Y. P. Li, "Quality evaluation for composting products through fuzzy latent component analysis," Resources, Conservation and Recycling, vol. 52, no. 10, pp. 1132-1140, 2008.

[14] A. A. Zorpas, A. G. Vlyssides, and M. Loizidou, "Dewatered anaerobically-stabilized primary sewage sludge composting: metal leachability and uptake by natural clinoptilolite," Communications in Soil Science and Plant Analysis, vol. 30, no. 1112, pp. 1603-1613, 1999.

[15] E. Marinos, "Lagooning concentration of olive oil processing wastewaters," in Proceedings of International Conference in Olive Oil Processing Wastewater Treatment Methods, pp. 165175, Crete, Greece, 1991.

[16] G. Boari, A. Brunetti, R. Passino, and A. Rozzi, "Anaerobic digestion of olive oil mill wastewaters," Agricultural Wastes, vol. 10, no. 3, pp. 161-175, 1984.

[17] A. A. Zorpas, "Sewage sludge compost evaluation in Oats, Pepper and Eggplant cultivation," Dynamic Soil, Dynamic Plant - Global Science Books, vol. 2, no. 2, pp. 103-109, 2008.

[18] R. Haug, Compost Engineering: Principles and Practice, Technomic Publishing Company, Lancaster, Pa, USA, 1980.

[19] A. A. Zorpas, Development of a methodology for the composting of sewage sludge using zeolite, Ph.D. thesis, National Technical University of Athens, Athens, Greece, 1999.

[20] A. A. Zorpas, V. Stamatis, G. A. Zorpas, A. G. Vlyssides, and M. Loizidou, "Compost characteristics from sewage sludge and organic fraction of municipal solid waste," Fresenius Environmental Bulletin, vol. 8, no. 3-4, pp. 154-162, 1999. 
[21] A. A. Zorpas, E. Kapetanios, G. A. Zorpas et al., "Compost produced from organic fraction of municipal solid waste, primary stabilized sewage sludge and natural zeolite," Journal of Hazardous Materials, vol. 77, no. 1-3, pp. 149-159, 2000.

[22] A. A. Zorpas, T. Constantinides, A. G. Vlyssides, I. Haralambous, and M. Loizidou, "Heavy metal uptake by natural zeolite and metals partitioning in sewage sludge compost," Bioresource Technology, vol. 72, no. 2, pp. 113-119, 2000.

[23] C. P. Huang, C. Dong, and Z. Tang, "Advanced chemical oxidation: its present role and potential future in hazardous waste treatment," Waste Management, vol. 13, no. 5-7, pp. 361-377, 1993.

[24] K. Swaminathan, S. Sandhya, A. C. Sophia, K. Pachhade, and Y. V. Subrahmanyam, "Decolorization and degradation of $\mathrm{H}-$ acid and other dyes using ferrous-hydrogen peroxide system," Chemosphere, vol. 50, no. 5, pp. 619-625, 2003.

[25] T. H. Kim, C. Park, J. Yang, and S. Kim, "Comparison of disperse and reactive dye removals by chemical coagulation and Fenton oxidation," Journal of Hazardous Materials, vol. 112, no. 1-2, pp. 95-103, 2004.

[26] S. Meriç, D. Kaptan, and T. Ölmez, "Color and COD removal from wastewater containing Reactive Black 5 using Fenton's oxidation process," Chemosphere, vol. 54, no. 3, pp. 435-441, 2004.

[27] S. Meriç, H. Selçuk, and V. Belgiorno, "Acute toxicity removal in textile finishing wastewater by Fenton's oxidation, ozone and coagulation-flocculation processes," Water Research, vol. 39, no. 6, pp. 1147-1153, 2005.

[28] R. J. Bidga, "Consider Fenton's chemistry for wastewater treatment," Chemical Engineering Progress, vol. 91, no. 12, pp. 62-66, 1995.

[29] Y. W. Kang and K. Y. Hwang, "Effects of reaction conditions on the oxidation efficiency in the Fenton process," Water Research, vol. 34, no. 10, pp. 2786-2790, 2000.

[30] X. R. Xu, Z. Y. Zhao, X. Y. Li, and JI. D. Gu, "Chemical oxidative degradation of methyl tert-butyl ether in aqueous solution by Fenton's reagent," Chemosphere, vol. 55, no. 1, pp. 73-79, 2004.

[31] M. Altinbas, A. F. Aydin, M. F. Sevimli, and I. Ozturk, "Advanced oxidation of biologically pretreated baker's yeast industry effluents for high recalcitrant COD and color removal," Journal of Environmental Science and Health, Part A, vol. 38, no. 10, pp. 2229-2240, 2003.

[32] H. J. H. Fenton, "Oxidation of tartaric acid in presence of iron," Journal of the Chemical Society, vol. 65, pp. 899-910, 1894.

[33] A. P. Murphy, W. J. Boegli, M. K. Price, and C. D. Moody, "A fenton-like reaction to neutralize formaldehyde waste solutions," Environmental Science and Technology, vol. 23, no. 2, pp. 166-169, 1989.

[34] S. H. Gau and F. S. Chang, "Improved fenton method to remove recalcitrant organics in landfill leachate," Water Science and Technology, vol. 34, no. 7-8, pp. 455-462, 1996.

[35] A. A. Burbano, D. D. Dionysiou, M. T. Suidan, and T. L. Richardson, "Oxidation kinetics and effect of $\mathrm{pH}$ on the degradation of MTBE with Fenton reagent," Water Research, vol. 39, no. 1, pp. 107-118, 2005.

[36] M. I. Badawy, M. Y. Ghaly, and T. A. Gad-Allah, "Advanced oxidation processes for the removal of organophosphorus pesticides from wastewater," Desalination, vol. 194, no. 1-3, pp. 166-175, 2006.

[37] E. Epstein, The Science of Composting, Technomic Publishing Company, Lancaster, Pa, USA, 1996.
[38] USDA, Composting. Part 637, National Engineering Handbook, NRCS, U.S. Department of Agriculture, Washington, DC, USA, 2000.

[39] A. A. Zorpas and M. Loizidou, "Sawdust and natural zeolite as a bulking agent for improving quality of a composting product from anaerobically stabilized sewage sludge," Bioresource Technology, vol. 99, no. 16, pp. 7545-7552, 2008.

[40] M. Fang, J. W. C. Wong, K. K. Ma, and M. H. Wong, "Co-composting of sewage sludge and coal fly ash: nutrient transformations," Bioresource Technology, vol. 67, no. 1, pp. 19-24, 1999.

[41] J. L. De Maeseneer, "Constructed wetlands for sludge dewatering," Water Science and Technology, vol. 35, no. 5, pp. 279-285, 1997.

[42] J. De Jong, "Purification of wastewater with the aid of rush or reed ponds," in Biological Conrrol of Water Pollution, J. Tourbier and R. W. Pierson, Eds., pp. 133-139, University of Pennsylvania Press, Philadelphia, Pa, USA, 1976.

[43] P. F. Cooper, State of Knowledge on Reed Bed Treatmenr Systems, Water Research Centre Processes, Stevenage, UK, 1987.

[44] K. Bucksteeg, "Treatment of domestic sewage in emergent helophyte beds. German experiences and ATV Guidelines $\mathrm{H}$ 262," in Proceedings of the International Conference on the Use of Constructed Wetlands in Water Pollution Conrrol, pp. 505515, Cambridge, UK, September 1990.

[45] L. Mandi, B. Houhoum, S. Asmama, and J. Schwartzbrod, "Wastewater treatment by reed beds: an experimental approach," Water Research, vol. 30, no. 9, pp. 2009-2016, 1996.

[46] S. M. Haslam, "Some aspects of the life history and autecology of Phragmites communis Trin.: a review," Polish Archives of Hydrobiology, vol. 20, no. 1, pp. 79-100, 1973.

[47] C. Den Hartog, J. Květ, and H. Sukopp, "Reed. A common species in decline," Aquatic Botany, vol. 35, no. 1, pp. 1-4, 1989.

[48] A. Lienard, C. Boutin, and D. Esser, "Domestic wastewater treatment with emergent helophyte beds in France," in Advances in Water Pollution Conrrol, pp. 183-192, Pergamon Press, 1990.

[49] R. Haberl and R. Perfler, "Nutrient removal in a reed bed system," Water Science and Technology, vol. 23, no. 4-6, pp. 729-737, 1991.

[50] H. Brix and H. H. Schiereup, "Danish experience with sewage treatment in wetlands," in Compte rendu de conferences: Constructed Wetlands for Wastewater Treatment Municipal, Industrial and Agricultural, D. A. Hammer, Ed., pp. 565-573, CRC Press, Chelsea, Mich, USA, 1990.

[51] J. Puigagut, J. Villaseñor, J. J. Salas, E. Bécares, and J. García, "Subsurface-flow constructed wetlands in Spain for the sanitation of small communities: a comparative study," Ecological Engineering, vol. 30, no. 4, pp. 312-319, 2007.

[52] M. Hardej and T. Ozimek, "The effect of sewage sludge flooding on growth and morphometric parameters of Phragmites australis (Cav.) Trin. ex Steudel," Ecological Engineering, vol. 18, no. 3, pp. 343-350, 2002.

[53] R. H. Kadlec and R. L. Knight, Treatment Wetlands, CRC Press, Boca Raton, Fla, USA, 1996.

[54] R. G. Wetzel, "Fundamental processes within natural and constructed wetland ecosystems: Short-term vs. Longterm objectives," in Proceedings of the 7th International Conference on Wetland Systems for Water Pollution Control, pp. 3-12, Lake Buena Vista, Fla, USA, November 2000.

[55] E. Meers, D. P. L. Rousseau, N. Blomme et al., "Tertiary treatment of the liquid fraction of pig manure with Phragmites 
australis," Water, Air, and Soil Pollution, vol. 160, no. 1-4, pp. 15-26, 2005.

[56] M. Bayley, "Nitrogen removal from domestic effluent using subsurface flow constructed wetland: influence of depth, hydraulic residence time and pre-nitrification," in Proceedings of 8th International Conference on Wetland Systems for water Pollution Control, p. 304, Dar Es Salam, Tanzania, 2002.

[57] M. Del Bubba, L. Checchini, C. Pifferi, L. Zanieri, and L. Lepri, "Olive mill wastewater treatment by a pilot-scale subsurface horizontal flow (SSF-h) constructed wetland," Annali di Chimica, vol. 94, no. 12, pp. 875-887, 2004.

[58] R. L. Knight, R. H. Kadlec, and H. M. Ohlendorf, "The use of treatment wetlands for petroleum industry effluents," Environmental Science and Technology, vol. 33, no. 7, pp. 973980, 1999.

[59] APHA AWWA-WPCF, Standard Methods for the Examination of Water and Wastewater, American Public Health Association, Washington, DC, USA, 10th edition, 1995.

[60] V. A. Dean, Water and Wastewater Examination Manual, Lewis Publishers, Chelsea, Mich, USA, 1990.

[61] A. A. Zorpas, A. G. Vlyssides, and M. Loizidou, "Physical and chemical characterization of anaerobically stabilized primary sewage sludge," Fresenius Environmental Bulletin, vol. 7, no. 78, pp. 502-508, 1998.

[62] A. A. Zorpas, A. G. Vlyssides, and G. A. Zorpas, "Metal removal from primary sewage sludge by elution with $\mathrm{HNO}$ solutions," Fresenius Environmental Bulletin, vol. 7, no. 11-12, pp. 681-687, 1998.

[63] D. Atanassova, P. Kefalas, and E. Psillakis, "Measuring the antioxidant activity of olive oil mill wastewater using chemiluminescence," Environment International, vol. 31, no. 2, pp. 275-280, 2005.

[64] M. Schnitzer, Methods of Soil Analysis, Part 2, Soil Science Society of America, Madison, Wis, USA, 9th edition, 1982.

[65] A. F. Gaudy Jr., "Colorimetric Determination of Protein and Carbohydrate," Industrial Waste Water, vol. 7, pp. 17-22, 1962.

[66] Handbook of Reference Methods for Soil Analysis, Georgia University Station, Athens, Ga, USA, 1992.

[67] M. S. Finstein, F. C. Miller, S. T. MacGregor, and K. M. Psarianos, "The Rutgers strategy for composting: process desing and control," in Proceedings of the International Symposium on Compost Recycling of Waste, Acta Horticulturae 302, pp. 75-86, Athens, Greece, March 1992.

[68] W. J. Jewell and R. M. Kabrick, "Autoheated aerobic thermophilic digestion with aeration," Journal of the Water Pollution Control Federation, vol. 52, no. 3, pp. 512-523, 1980.

[69] Y. P. Alder, E. V. Markova, and Y. V. Granovsky, The Design of Experiments to Find Optimal Conditions, Mir Publisher, Moscow, Russia, 1995.

[70] W. C. Cochran and G. M. Cox, Experimental Designs, John Wiley \& Sons, New York, NY, USA, 1957.

[71] H. El Hajjouji, N. Fakharedine, G. Ait Baddi et al., "Treatment of olive mill waste-water by aerobic biodegradation: an analytical study using gel permeation chromatography, ultravioletvisible and Fourier transform infrared spectroscopy," Bioresource Technology, vol. 98, no. 18, pp. 3513-3520, 2007.

[72] F. J. Rivas, F. J. Beltrán, O. Gimeno, and J. Frades, "Treatment of olive oil mill wastewater by Fenton's reagent," Journal of Agricultural and Food Chemistry, vol. 49, no. 4, pp. 1873-1880, 2001.

[73] A. A. Zorpas, D. Arapoglou, and K. Panagiotis, "Waste paper and clinoptilolite as a bulking material with dewatered anaerobically stabilized primary sewage sludge (DASPSS) for compost production," Waste Management, vol. 23, no. 1, pp. $27-35,2003$.

[74] F. Herrera, C. Pulgarin, V. Nadtochenko, and J. Kiwi, "Accelerated photo-oxidation of concentrated p-coumaric acid in homogeneous solution. Mechanistic studies, intermediates and precursors formed in the dark," Applied Catalysis B, vol. 17, no. 1-2, pp. 141-156, 1998.

[75] M. A. Miranda, F. Galindo, A. M. Amat, and A. Arques, "Pyrylium salt-photosensitized degradation of phenolic contaminants derived from cinnamic acid with solar light correlation of the observed reactivities with fluorescence quenching," Applied Catalysis B, vol. 28, no. 2, pp. 127-133, 2000.

[76] M. A. Miranda, F. Galindo, A. M. Amat, and A. Arques, "Pyrylium salt-photosensitised degradation of phenolic contaminants present in olive oil wastewaters with solar light Part II. Benzoic acid derivatives," Applied Catalysis B, vol. 30, no. 3-4, pp. 437-444, 2001.

[77] M. A. Miranda, M. L. Marín, A. M. Amat, A. Arques, and S. Seguí, "Pyrylium salt-photosensitized degradation of phenolic contaminants present in olive oil wastewater with solar light Part III. Tyrosol and p-hydroxyphenylacetic acid," Applied Catalysis B, vol. 35, no. 3, pp. 167-174, 2002.

[78] A. M. Amat, A. Arques, H. Beneyto, A. García, M. A. Miranda, and S. Seguí, "Ozonisation coupled with biological degradation for treatment of phenolic pollutants: a mechanistically based study," Chemosphere, vol. 53, no. 1, pp. 79-86, 2003.

[79] W. Gernjak, T. Krutzler, A. Glaser et al., "Photo-fenton treatment of water containing natural phenolic pollutants," Chemosphere, vol. 50, no. 1, pp. 71-78, 2003.

[80] D. Mantzavinos, "Removal of cinnamic acid derivatives from aqueous effluents by fenton and fenton-like processes as an alternative to direct biological treatment," Water, Air, and Soil Pollution: Focus, vol. 3, no. 3, pp. 211-221, 2003.

[81] D. Mantzavinos, "Removal of benzoic acid derivatives from aqueous effluents by the catalytic decomposition of hydrogen peroxide," Process Safety and Environmental Protection, vol. 81, no. 2, pp. 99-106, 2003.

[82] E. G. Kapetanios, M. Loizidou, and G. Valkanas, "Compost production from Greek domestic refuse," Bioresource Technology, vol. 44, no. 1, pp. 13-16, 1993.

[83] A. Parvaresh, M. R. Shahmansouri, and H. Alidadi, "Determination of Carbon/Nitrogen ratio and heavy metals in bulking agents used for sewage composting," Iranian Journal of Public Health, vol. 33, no. 2, pp. 20-23, 2004.

[84] E. I. Jimenez and V. P. Garcia, "Composting of domestic refuse and sewage sludge. II. Evolution of carbon and some "humification" indexes," Resources, Conservation and Recycling, vol. 6, no. 3, pp. 243-257, 1992.

[85] M. Ros, C. García, and M. T. Hernandez, "Evaluation of different pig slurry composts as fertilizer of horticultural crops: effects on selected chemical and microbial properties," Renewable Agriculture and Food Systems, vol. 22, no. 4, pp. 307-315, 2007.

[86] X. T. He, T. J. Logan, and S. J. Traina, "Physical and chemical characteristics of selected U.S. municipal solid waste composts," Journal of Environmental Quality, vol. 24, no. 3, pp. 543-552, 1995.

[87] J. A. Alburquerque, J. Gonzálvez, D. García, and J. Cegarra, "Measuring detoxification and maturity in compost made from "alperujo", the solid by-product of extracting olive oil by the two-phase centrifugation system," Chemosphere, vol. 64, no. 3, pp. 470-477, 2006. 
[88] European Commission, "Working document: biological treatment of biowaste, 2nd draft," pp. 1-22, 2001.

[89] European Commission, "Working document: biological treatment of biowaste, 2nd draft," pp. 1-22, 2005. 

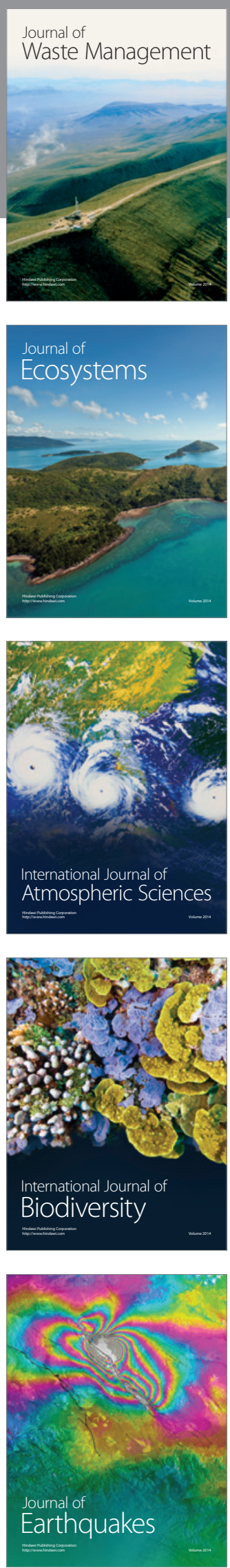
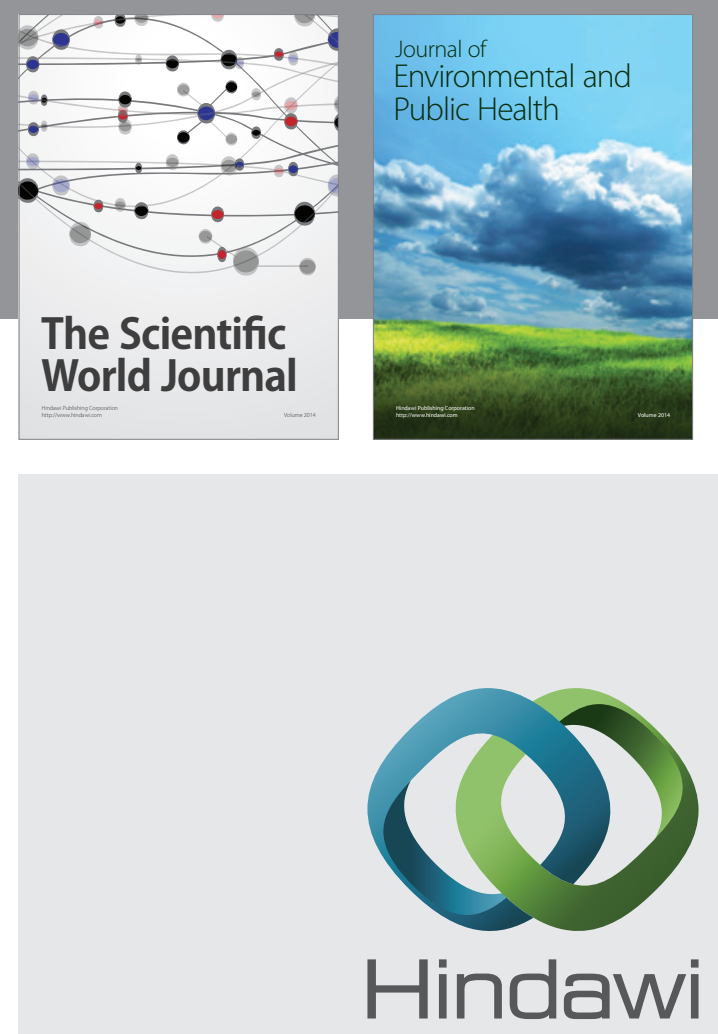

Submit your manuscripts at

http://www.hindawi.com
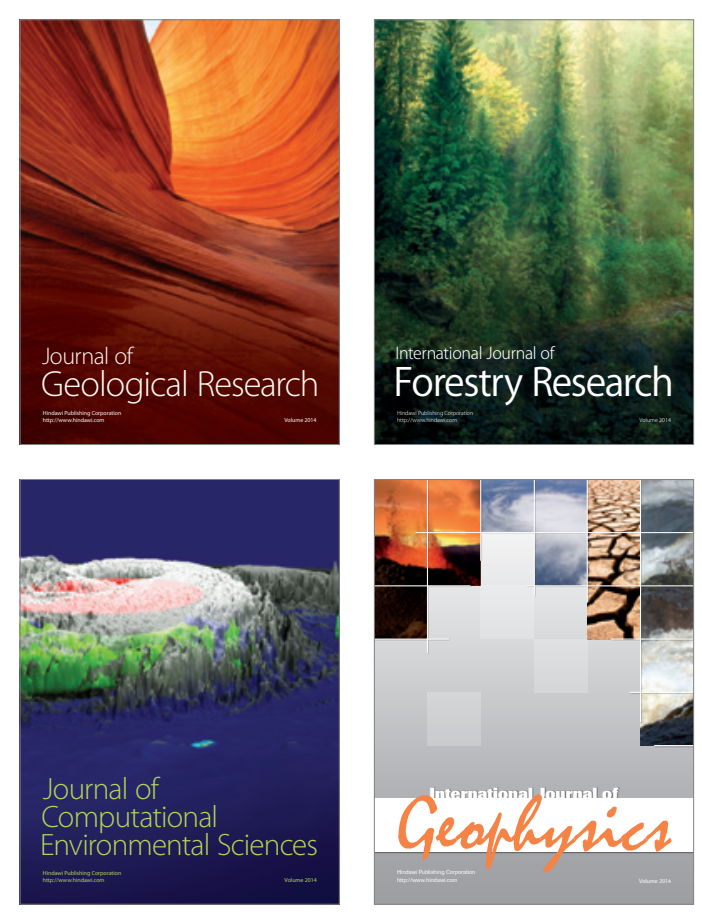
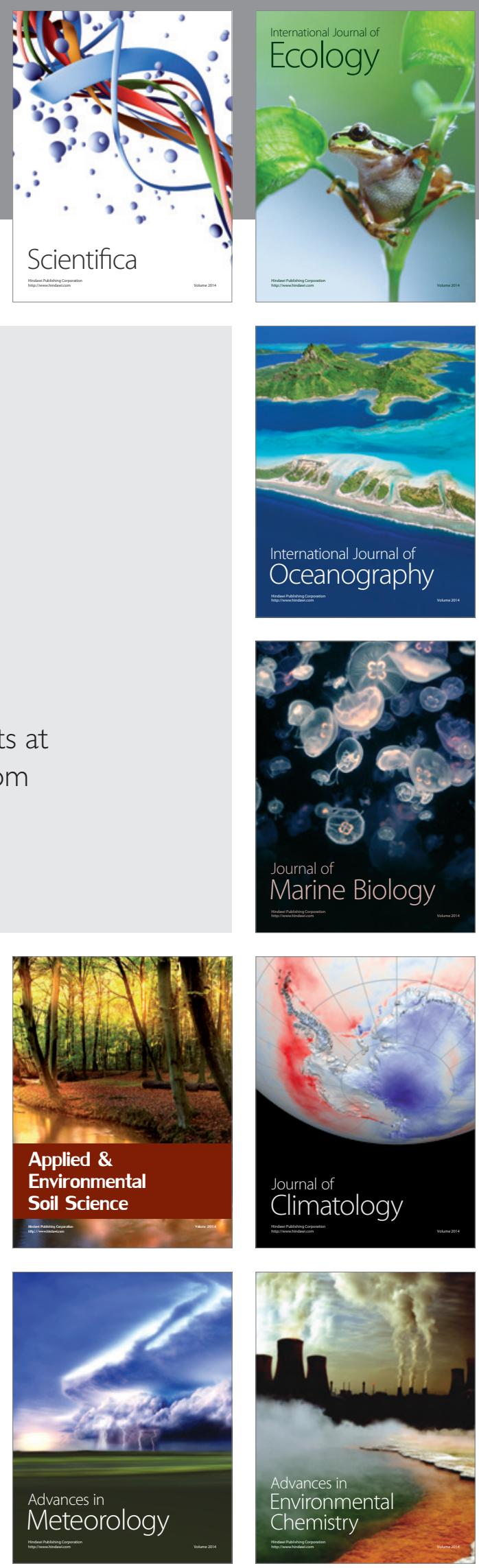